\title{
CRANIAL NEUROIMAGING IN INFANTILE TREMOR SYNDROME
}

\author{
Ashu Jamwal ${ }^{1}$, Sunil Dutt Sharmaㄹ ${ }^{2}$ Ghanshyam Saini ${ }^{3}$
}

\section{HOW TO CITE THIS ARTICLE:}

Ashu Jamwal, Sunil Dutt Sharma, Ghanshyam Saini. "Cranial Neuroimaging in Infantile Tremor Syndrome". Journal of Evolution of Medical and Dental Sciences 2015; Vol. 4, Issue 44, June 01; Page: 7643-7646, DOI: $10.14260 /$ jemds/2015/1109

ABSTRACT: BACKGROUND: Infantile Tremor syndrome is a clinical disorder characterised by coarse tremors, anemia and regression of motor and mental milestones in children around one year of age. These children are listless, apathetic and have tremors which may be attributed to structural and functional alterations of the brain. AIM: The aim of the study was to find any such structural changes in the brain in the patients with ITS. METHODS: A prospective study was conducted of ten such cases admitted in department of Pediatrics, SMGS Hospital, Medical College Jammu w.e.f. March 2013 to 2015. T1, T2 \& flair images in MRI were obtained for all the subjects. OBSERVATIONS AND RESULTS: The MRI findings noted were primary hypomyelination, cerebral atrophy, dilatation of ventricular system and extracerebral spaces. Cerebral atrophy was most common finding present in 8 out of 10 cases, while dilatation of ventricles and prominence of extracerebral CSF spaces was the next common finding. Thinning of the corpus callosum was seen in three cases. CONCLUSION: Although the changes found appear to be nonspecific and have been reported previously, we got three patients with thinning of corpus callosum, an association which we could not find in literature available.

KEYWORDS: ITS, cerebral atrophy, corpus callosum.

INTRODUCTION: Infantile Tremor syndrome is clinical disorder reported both in and outside India especially in South East Asian countries,(1,2) It is characterised by coarse tremors, anemia, hyperpigmentation and regression of motor and mental milestones, basis of origin of which is not clearly understood.(3) It is seen in children around one year of age who are mostly on prolonged exclusive breastfeeding from predominantly vegetarian mothers. A classical picture of ITS is a plump, anemic, malnourished infant between 6 months to 18 months with sparse and light coloured scalp hair. These children are listless, apathetic and disinterested in surroundings. The presence of tremors and neuromotor regression are the most prominent neurological manifestations attributed to structural and functional alterations of brain especially the extrapyramidal system.(4,5) The causation of ITS is of much debate. Malnutrition, vitamins and mineral deficiency (e.g., Mg, Zn, Vit. B12, iron), infections, toxins, degenerative brain diseases, enzyme defects (e.g., tyrosine), all have been postulated as the cause of ITS.(6,7) Garewal et al. described it as a Vitamin B12 deficiency syndrome. He postulated that low levels of vit. B12 and its transport protein TC II in the CSF may be responsible for the neurological features of this syndrome.(8) Goraya et al found low serum vitamin B12 levels in 8 out of 16 infants with ITS. Six of the 8 infants with normal B12 levels had received Vitamin B12 before referral. Also treatment with Vitamin B 12 alone produced rapid recovery. ${ }^{(9)}$

Since regression of milestones and tremors of various parts of body point to some kind of neurological disturbances in brain in such cases, we decided to do MRI in these cases to find out if we could get some structural abnormalities of the brain. Not much literature is available regarding the MRI findings in such cases which may be probably due to the fact that ITS is uncommon in most part of the world. 


\section{ORIGINAL ARTICLE}

We studied MRI findings of ten such cases of ITS, admitted in the Department of paediatrics, SMGS hospital, Medical College Jammu w.e.f. March 2013 to March 2015.

MATERIALS AND METHODS: Ten patients were included in this study. All of them were admitted in pediatric department of SMGS Hospital Jammu. Clinical features and proper history were the main diagnostic tools. All were exclusively breastfed without any weaning having been started. 7 were males and 3 were females with age between 6 months to 2 years. All had protein energy malnutrition with 8 cases having weight for age $\mathrm{Z}$ score values $<-3$ and two cases having values $-3<\mathrm{Z}$-score $<-2$ (WHO Growth standards). All of them had neuromotor regression and tremors. Tremors were more marked in hands and tongue. The tremors used to increase with activity and were absent during sleep. All children were pale, plump looking with cutaneous hyperpigmentation of knuckles. They had sparse, hypo pigmented hair. Out of ten, 4 came with chief complaints of tremors, 3 with gastroenteritis and rest with lower respiratory infections.

Children with evidence of CNS infection, present or past history of seizures, and any $\mathrm{H} / \mathrm{O}$ seizures in family were excluded from this study.

RESULTS: Their MRI findings are summarised in Table I.

\begin{tabular}{|c|c|c|c|c|}
\hline $\begin{array}{l}\text { Sl. } \\
\text { No. }\end{array}$ & AGE & SEX & $\begin{array}{l}\text { Weight for } \\
\text { age } \mathrm{Z} \text { score } \\
\text { values }\end{array}$ & NEUROIMAGING FINDINGS \\
\hline 1 & $9 \mathrm{~m}$ & $\mathrm{M}$ & $<-2$ to $<-3$ & Normal study \\
\hline 2 & $9 m$ & M & $<-3$ & $\begin{array}{l}\text { I. Paucity of white matter in cerebral hemespheres } \\
\text { with prominent CSF spaces. } \\
\text { II. Prominent CSF spaces both ventricles and } \\
\text { extracerebral spaces. } \\
\text { III. Thinning of corpus callosum. }\end{array}$ \\
\hline & $18 \mathrm{~m}$ & M & $<-3$ & $\begin{array}{l}\text { I. } \quad \text { Diffuse cerebral atrophy. } \\
\text { II. } \\
\text { Extracerebral CSF spaces, sylvian fissure and } \\
\text { cerebral ventricles are dilated. } \\
\text { III. } \text { Corpus callosum is mildly thin. }\end{array}$ \\
\hline 4 & $10 \mathrm{~m}$ & M & $<-3$ & $\begin{array}{ll}\text { I. } & \text { Diffuse cerebral atrophy. } \\
\text { II. } & \text { Cerebral ventricles mildly dilated. } \\
\text { III. } & \text { Cerebral sulci,B/L frontotemporoparietal region } \\
& \text { extracerebral CSF spaces sylvian fissure and } \\
& \text { interhemispheric fissure are dilated. }\end{array}$ \\
\hline 5 & $9 \mathrm{~m}$ & M & $<-3$ & $\begin{array}{ll}\text { I. } & \text { Paucity of white matter. } \\
\text { II. } & \text { Ventricular system and ECF spaces are prominent. } \\
\text { III. } & \text { Primary hyomyelination syndrome. }\end{array}$ \\
\hline 6 & $9 \mathrm{~m}$ & M & $<-3$ & $\begin{array}{l}\text { I. Mild prominence of sylvian fissure and } \\
\text { extracerebral spaces and supratentorial ventricular } \\
\text { system s/o reduced brain matter. } \\
\text { II. } \\
\text { Mild cerebral atrophy. } \\
\text { III. Thinning of corpus callosum. }\end{array}$ \\
\hline
\end{tabular}




\section{ORIGINAL ARTICLE}

\begin{tabular}{|c|c|c|c|c|}
\hline 7 & $1 \mathrm{yr}$ & $\mathrm{F}$ & $<-3$ & $\begin{array}{ll}\text { I. } & \text { Cerebral atrophy. } \\
\text { II. } & \text { Mild dilatation of CSF spaces. } \\
\text { III. } & \text { Hyperintense signals from frontal lobe. }\end{array}$ \\
\hline 8 & $1 \mathrm{yr}$ & $\mathrm{F}$ & $<-2$ to $<-3$ & Normal study. \\
\hline 9 & $9 \mathrm{~m}$ & $\mathrm{M}$ & $<-3$ & Mild cerebral atrophy. \\
\hline 10 & $8 m$ & $\mathrm{~F}$ & $<-3$ & $\begin{array}{ll}\text { I. } & \text { Mild dilatation of CSF spaces. } \\
\text { II. } & \text { Mild cerebral atrophy. }\end{array}$ \\
\hline
\end{tabular}

DISCUSSION: The findings on MRI images (T1, T2, and Flair images) were cerebral atrophy, primary hypomyelination, dilatation of ventricles system and ECF spaces and thinning of corpus callosum. Two cases were reported to have normal MRI, rest eight had some or other form of abnormality. 7 cases had dilatation of ventricles and ECF spaces. 8 had diffuse cerebral atrophy. 2 cases showed mild thinning of corpus callosum. Hyperintense signals were obtained in two cases in frontal and periventricular white matter on $\mathrm{T} 2$ weighted images which may signify demyelination secondary to some insult. Thus we were able to find certain structural changes on MRI. In these cases our findings were consistent with few other studies carried out in the past.

Nonspecific structural changes have been reported on cranial neuroimaging, which may also be found in cases of malnutrition especially in acute and recovery phases.(10,11,12) Few reports of neuroimaging abnormalities in children with ITS are present in literature. Most common findings of neuroimaging in ITS is cerebral atrophy with ex-vacuo enlargement of ventricles and subarachnoid spaces.(13,14,15) One report has shown pontine myelenosis and cerebral hyperintensities.(16) Hyperintense signal in frontal and periventricular white matter on T2 weighted images in MRI scan may signify demyelenation or edema and necrosis secondary to some ischemic insult which in turn may occur due to some acute viral infection or parainfectious acute demyelenating encephalopathy.(17)

CONCLUSION: Cerebral atrophy was most common finding present in 8 out of 10 cases, while dilatation of ventricles and prominence of extracerebral CSF spaces was the next common finding. Three of our cases had thinning of corpus callosum, an association which had not been reported earlier. Further functional brain studies need to be carried out to see if these finding are significant enough to cause neuromotor regression and also correlate the findings with the severity and duration of neurological symptoms.

\section{REFERENCES:}

1. Gupte S. Infantile tremor syndrome In: Gupte S, editor The Short Textbook of Paediatrics. $11^{\text {th }}$ ed. New Delhi: Jaypee Brothers; 2009. pp. 726-8.

2. Amin NM, Zeki JM. Infantile Tremor Syndrome in Iraqi Kurdistan. Indian J Pediatr. 2005; 72 : 839-42.

3. Ghai. O. P, Gupta. P. Infantile tremor syndrome (ITS) In Ghai OP, Gupta P, Paul VK, eds. Ghai Essential Pediatrics 6 $6^{\text {th }}$ edn New Delhi: Dr Ghai; 2005, PP 539-540.

4. Kaul KK, Prasan M, Choudhary RM. Some clinical observations and impressions on a syndrome of tremors in infants from India. J Pediatr 1963; 63: 1158-1166. 


\section{ORIGINAL ARTICLE}

5. Schdev K.K, Manchanda S.S, Lal H. The syndrome of tremors, mental regression and anemia in infants and young children. A study of 102 cases. Indian Pediatr 1965; 2: 239-251.

6. Kalra V. Infantile Tremor Syndrome. In: Ghai OP, editor, Essential Pediatrics. $7^{\text {th }}$ ed New Delhi: CBS Publishers and Distributions Pvt Ltd; 2009.pp. 558-9.

7. Khan E.A, Neurological Syndrome in Infants Recovering from Malnutrition. Arch Dis Child 1954; 29: 256-61.

8. Garewal G, Narang A, Das K.C, ITS: A vitamin B 12 deficiency syndrome in infants J Trop Pediatr. 1988; 34: 174-8.

9. Goraya J.S, Kaur S. Infantile Tremor Syndrome - Down but not out. Indian Pediatr. 2015; 52: 249-50.

10. Engsner G, Habte D. Brain growth in children with kwashiorkar. Acta Pediatr Scand 1974; 1: 34-48.

11. Alleyene GAO, Hay R.W, Picou D.L, Stanfield J.P, Whitehead R.G. The pathology of malnutrition In: Protein Energy malnutrition. 1 ${ }^{\text {st }}$ Edn. New Delhi: Jaypee Brothers; 1988, pp 25-53.

12. Sachdev K. K. Encephalopathies. In Udani PM, editor. Textbook of Paediatrics. Revised $1^{\text {st }}$ edn. New Delhi: Jaypee Brother; 1998, p2134.

13. Thora S, Mehta N. Cranial neuroimaging in infantile tremor syndrome (ITS). Indian Pediatr. 2007; 44: 218-20.

14. Muzali M.V, Sharma P.P, Kaul P.B, Gupta P. Carbamazepine therapy for infantile tremor syndrome. Indian Pediatr. 1993; 30: 72-4.

15. Ratageri V.H, Shepur T.A, Patil M.M, Hakim M.A. Scurvy in infantile tremor syndrome. Indian J Pediatr. 2005; 72: 883-4.

16. Datta K, Datta S, Dutta I. Rare association of central pontine myelinosis with infantile tremor syndrome. Ann Indian Acad Neurol 2012; 15: 48-50.

17. Gordon K Sze. Infections and inflammation. In: Stark David D, Bradley William G. eds. Magnetic Resonance Imaging. 3rd edn. St Louis Mosby; 1999, p. 1361-1377.

\section{AUTHORS:}

1. Ashu Jamwal

2. Sunil Dutt Sharma

3. Ghanshyam Saini

\section{PARTICULARS OF CONTRIBUTORS:}

1. Assistant Professor, Department of Paediatrics, SMGS Hospital, GMC, Jammu.

2. Assistant Professor, Department of Paediatrics, SMGS Hospital, GMC, Jammu.

FINANCIAL OR OTHER COMPETING INTERESTS: None
3. Professor, Department of Paediatrics, SMGS Hospital, GMC, Jammu.

\section{NAME ADDRESS EMAIL ID OF THE CORRESPONDING AUTHOR:}

Dr. Ashu Jamwal, \# 356 A, Gandhinagar, Jammu-180004, Jammu \& Kashmir.

E-mail: ashu.sainik@gmail.com

Date of Submission: 08/05/2015. Date of Peer Review: 09/05/2015. Date of Acceptance: 23/05/2015. Date of Publishing: 30/05/2015. 